\title{
O ESPAÇO MENTAL DE BALTASAR GRACIÁN: ACERCA DA FASCINAÇÃO DE UMA CONCRETUDE FRIA ${ }^{1}$
}

\author{
Hans Ulrich Gumbrecht 1 \\ -Stanford University, Stanford, California, USA \\ Tradução de Luiz Costa Lima² \\ 2Pontifícia Universidade Católica do Rio de Janeiro, Rio de Janeiro, Rio de \\ Janeiro, Brasil
}

Como os outros autores clássicos da época de ouro na cultura hispânica, desde o final do século XVI até meados do século XVII, como Miguel de Cervantes, Lope Félix de Vega, Pedro Calderón de la Barca ou Luis de Góngora, também o jesuíta predicante e teólogo Baltasar Gracián imprime à sua contemporaneidade e posteridade uma figura de perfil marcante, a que sua obra e condição de vida tanto caracterizam quanto iluminam. À diferença dos grandes contemporâneos e, exatamente, embora os textos de Gracián possam se mostrar muito homogêneos no que concerne a gênero e conteúdo, provocavam com sua erudição imponente aspectos sempre específicos: seu lugar na tradição histórica e filológica, problemas filológicos isolados de difícil resolução ou momentos particularmente intensos da história da recepção. Por isso o contorno de sua figura autoral no final das contas mal se preenche com uma imagem individual pintada.

Quanto à sua origem e seu resultado, isso procede com a monumental exceção do livro do hispanista alemão Werner Krauss,

\footnotetext{
1 Gracián Baltasar. Handorakel und Kunst der Weltklugheit. Neuübersetzung. Übers. und hrsg. von Hans Ulrich Gumbrecht. Stuttgart: Philipp Reclam jun., 2020, pp. 173-214.
} 
Graciáns Lebenslehre (A Concepção de vida de Gracián), publicado pela primeira vez em 1947. ${ }^{2}$ Para começar, diversas razões levam a que se louve uma nota preliminar obrigatória notavelmente lacônica, que há de ser citada sem cortes:

\begin{abstract}
Este trabalho foi escrito, sob circunstâncias singulares, em 1943. O autor dependia das edições de Gracián, que lhe foram generosamente colocadas à disposição. Não teve acesso à bibliografia secundária. Se, depois da liberação, uma mudança fundamental não sucedesse, assim se deu na suposição de que uma exposição da concepção de vida de Gracián, a partir de seus próprios pressupostos, mesmo sem uma precisa coordenação filológico-histórica, é passível de servir a um interesse geral (Krauss, W.: 1947, sem indicação de página)
\end{abstract}

Com a fórmula aparentemente acidental das "circunstâncias singulares" na origem da obra sobre Baltasar Gracián, Krauss remetia à detenção de vinte meses na cela de morte da prisão berlinense de Plötzensee, entre janeiro de 1943 e setembro de 1944. Nascido em 1900, Krauss estudara em Madri de 1922 a 1926, se doutorara em Munique, sob a supervisão de Karl Vossler com um trabalho sobre Alltagsleben und Literatur im spanischen Mittelalter (Vida cotidiana e literatura na Idade média espanhola), para trabalhar nos anos 1930 como assistente do eminente romanista judeu Erich Auerbach, na Universidade de Marburg. No começo da Segunda Guerra Mundial, Krauss foi transferido para uma equipe de tradutores em Berlim. No fim de 1942, devido a atividades de propaganda antinazista ele foi preso juntamente com sua companheira 17 anos mais jovem, Ursula Götze, e condenado à morte. Enquanto as autoridades alemãs decapitavam Ursula Götze em agosto de 1943, Krauss sobrevivia graças à intervenção de colegas proeminentes, que con-

\footnotetext{
${ }^{2}$ Vittorio Klostermann Verlag, Frankfurt am Main, aqui citado de acordo com a terceira edição inalterada de 2013.
} 
seguiram uma transformação da primeira decisão em detenção de cinco anos. Terminada a guerra, surgiu na República Democrática Alemã (Deutsche Demokratische Republik) sua significativa obra científica, sobretudo sobre o iluminismo francês, tomado como um legado cultural de força normativa.

Como se explica a decisão de Werner Krauss, face à proximidade da morte, de - além do satírico romance cifrado Die Passionen der halkyonischen Seele (As paixões da alma tranquila), editado também depois de 1945 - escrever um livro³ sobre o jesuíta Gracián, cujo centro é ocupado pela coleção de aforismos intitulada Oráculo manual, publicada em 1647? Já a última frase de sua "nota preliminar" que tende a ser cientificamente mais complicada e então soa existencialmente mais inocente indica uma resposta. A concepção de vida de Gracián, considera Krauss, funda-se a tal ponto na força salvadora de premissas e argumentos racionais nas situações precárias, que a orientação existencial adquirida se faz independente das circunstâncias específicas de seu surgimento. Isso ainda seria válido, ressalta na parte final de seu livro, para a metade do século XX:

Gracián poderia ser visto em certo sentido como um precursor da psicologia moderna. Mas sua concepção de mundo transcorre naturalmente em direção diferente, até mesmo na direção oposta. Enquanto a moderna psicologia profunda parte das correntes do irracionalismo, a pesquisa de Gracián conduz a ampliar e a consolidar um novo horizonte anímico para o domínio da soberania humana, na linha das posturas do espiritualismo aristocrático do começo do iluminismo. [...] A legalidade inquebrantável da criação à maneira de Gracián do homem ligado a si mesmo pode por isso valer como uma prova de que também no campo anímico as descobertas efetivamente fecundas não resultam de falhas impensadas de todo o saber transmitido, senão de seu poder ousadamente reunido para uma finalidade renovada. ${ }^{4}$

\footnotetext{
${ }^{3}$ Entre os alunos de Krauss corria o rumor que o livro fora escrito "em algemas". ${ }^{4}$ Ob. cit., 160-1.
} 
Estas frases nos permitem formular uma primeira tese sobre a fascinação potencial de um texto do século XVII para nossa contemporaneidade. Krauss parece supor que justamente o começo do iluminismo parte da possibilidade historicamente aberta de descobrir "regularidades" abstratas nas formas de vida do "homem ligado a si mesmo" e para isso empregava, em vez da revelação divina ou da lembrança do valor da humanidade, toda a gama do saber ligado na recente compressão racional. Ainda com bastante independência de conteúdos e formas específicos com que o texto de Gracián nos chega, ele nos encoraja à ousadia de uma autonomia individual (Krauss fala da "soberania humana") na condução da vida e em suas reflexões precedentes. Helmut Lethen descreveu a abstração distante daquela forma mental como "fria" (também no sentido de "dotada de sangue frio") e com isso esclarece sua fascinação para os intelectuais de posições extremas ${ }^{5}$. O apelo a tal frieza da reflexão, com que Werner Krauss sobreviveu na cela de morte de Plötzensee, pode ser proveitosa para nossa existência na complexidade tão diversa do cotidiano atual. Para que possa contribuir para isso, deve antes de tudo permanecer aberto particularmente o estilo com que, no Oráculo manual, conceitos e argumentos foram expressos.

Aquela racionalidade abstrata da Idade Moderna no pensamento de Baltasar Gracián, que ignora padrões mentais historicamente específicos dos novos tempos, esclarece por um lado uma dimensão de duração específica na recepção de suas sete obras.

${ }^{5}$ Verhaltenslehren der Kälte. Lebensversuche zwischen den Weltkriegen, Frankfurt am Main, 1994; do mesmo autor: Suche nach dem Handorakel. Ein Bericht, Göttingen, 2012, com referência a Gracián e Krauss no capítulo "Vom Finden und dem Verlust des Handorakels", pp. 114-125. Sobre a abstração e distância como tendências do pensamento na concepção histórica de Gracián, $c f$. Leonie Pawlita: Staging doubt. Skepticism in early modern Europa drama, Berlim - Boston, 2019. 
Exceto o livro religioso de orações, El Comulgatorio, o único texto que, durante sua vida, apareceu com seu nome próprio, todos sempre encontraram leitores, por quase quatrocentos anos. Por outro lado, o Oráculo manual é como uma antologia dos pensamentos de Gracián, que apresentava aproximadamente o proscênio emblemático de sua obra e, ainda por cima - por motivos bastante distintos - encontrou uma ressonância particularmente intensa durante o restante do século XVII e novamente desde o século XIX.

No amplo contexto europeu, as obras seculares de Gracián pertenciam a um movimento heterogêneo de reflexão a respeito de estruturas e possibilidades de uma ação autônoma focada, ou seja, não mais religiosamente dirigida. Ele encontrara no Corteggiano (1528), de Baldassare Corteggiano, e no Principe (1532), de Niccolo Machiavelli, seu começo italiano e, durante a Idade de Ouro Espanhol, tivera sua continuidade com direcionamento menos específico a personalidades eminentes da aristocracia e da corte para a seguir, no moralismo mais fortemente enfatizado que redunda em clássicos franceses, como la Bruyère ou La Rochefoucauld.

Durante a vida de Gracián e no decênio depois de sua morte, em dezembro de 1658, pode haver dominado um uso prático-político dos traços de pensamento a ele ligados. O Oráculo manual foi um dos livros com que o rei Felipe IV regularmente se aconselhava ${ }^{7}$. Mas antes de tudo a tradução francesa livre e parafraseada do texto de Gracián por Amelot de la Houssaie, sob o título de L'Homme de cour (a partir de 1684) encontrou na corte de Luís XIV, em Versailles, leitores influentes ${ }^{8}$. Em uma direção semelhante - por certo, sem o horizonte de referência concreta do leitor possível - se

\footnotetext{
${ }^{6} C f$. o excelente prefácio de Emilio Blanco à sua edição do Oráculo manual y arte de pridencia de Baltasar Gracián, Letras Hispánicas, Madri, 1993, pp. 17 p- 87, precisamente pp 28 ss.

${ }^{7}$ Krauss, op. cit., p. 17.

${ }^{8}$ Sob o título "Traduire - de l' Oráculo manual à L'Homme de cour" - Roger Chartier detalhou o potencial de função na transmissão modificada do texto de Gracián, in Rager Chartier: L'oeuvre, l'atelier et la scène. Toiis études de mobilité textuelle, Paris, 2014, pp. 122- 137.
} 
dirigia a primeira tradução alemã do Oráculo manual, publicada entre 1715 e 1719, pelo professor August Friedrich Müller, de Leipzig, em que o compacto original cresceu em um tratado de 1.500 páginas ${ }^{9}$. Como a época do Iluminismo buscava suspender a racionalidade dos primórdios da Idade Moderna, voltada ao proveito individual, a uma "moral de todo o humano" (Lethen bem formularia: buscar suspender "no calor" de tal moral), cujo discurso desde então se tornou normativo para a consciência política, textos como o de Castiglione, Machiavelli ou Gracián o Iluminismo imbuía de um presságio negativo ${ }^{10}$. Mas, justamente, essa reserva mental crítica servia como uma segunda fase de intensidade na recepção do Oráculo manual à maneira de contraste e motivação. A ela pertencem até hoje as reações individuais, que forram o pathos especial do contraste extremo da chamada "moral burguesa" - não com base em uma reserva fundamental contra exigências morais, mas sim, em ceticismo face às possibilidades de sua realização.

O caso mais celebrado e, não só para a cultura alemã, mais rico de consequências da reação ao calor iluminista da humanidade é o entusiasmo de Arthur Schopenhauer por Gracián. Além disso, movido por suas condições financeiras precárias, ao que tudo indica somente três anos após iniciar o estudo do espanhol, Schopenhauer entusiasma-se no inverno de 1831/32 à tradução do Oráculo manual ao alemão ${ }^{11}$. Sua noticiada "Litterarischen Notiz" para o edi-

${ }^{9} C f$. Sebastian Neumeister em seu prefácio à edição revisada da tradução de Schopenhauer: Handorakels und Kunst der Weltklugheit, Stuttgart, 2013, pp. XV - XXX, mais precisamente p. XXV.

${ }^{10} C f$. a análise sutil da história da recepção de Gracián por Helmut Lethen: "Im reissenden Strom der Translationen. Der Gracián-Kick im 20. Jahrhundert”, in komparatisk online que, com documentação detalhada e matização impressionante descreve os casos mais importantes das leituras individualmente positivas.

11 Cf. David D. Cartwright, Schopenhauer: a biography, Cambridge, 2010, pp. 418 - 422, acerca dos postulados e consequências desta tradução na vida de Schopenhauer. Em contraposição a Neumeister, que escreve dos erros, incompreensões e equívocos" do tradutor, sustento que a versão de Schopenhauer do Oráculo manual como conteudisticamente marcante, apesar da tendência, plausível em face das dificuldades do original, das paráfrases e interpretações implícitas aqui e 
tor Friedrich Fleischer ainda ocultava, onde se encontrava o interesse particular do filósofo, fundado no ceticismo e no pessimismo:

O Oráculo manual ensina a arte do que se aplica a todos e é, portanto, para cada um. Mas particularmente é apropriado para se tornar o manual de todos que vivem no grande mundo, sobretudo dos jovens que se esforçam em aí conquistar sua felicidade e aos quais uma vez e antecipadamente fornece a instrução que se esmeram em manter por meio de longa experiência. ${ }^{12}$

Permanece inominada a "solidão do espírito pensante no interior de um ambiente incompreendido e hostil" ${ }^{13}$, que Schopenhauer ao que tudo indica encontrou em Gracián como um motivo da afinidade, e a compreensão de Gracián da vida como arena de luta existencial (como já se revela no 13. dos 300 aforismos do Oráculo manual). É assim provável que não unicamente a reivindicação financeira de Schopenhauer tenha feito com que a tradução só viesse a ser publicada em 1862, dois anos após sua morte, e que em numerosas e muito trabalhadas novas edições se convertesse em meio de uma fascinação especificamente alemã, cujos pressupostos sem embargo pertencem ao clima cultural do fim do século XIX. Daí que Friedrich Nietzsche, nos "Nachgelassenen Fragmenten" ("Fragmentos póstumos"), repita a referência a Gracián e associe seu pensamento a uma necessidade de conexão existencial não satisfeita do próprio tempo:

ali, por conta da grande distância quanto ao estilo de pensar e escrever de Gracián. ${ }^{12}$ Apud Neumeister, p. XXI.

${ }^{13}$ Assim em Werner von Koppenfels: "Graciáns (Über) Lebensjahre", posfácio a Baltasar Gracián: Handorakel und Kunst der Weltklugheit, Munique, $4^{\mathrm{a}}$ edição, 2013, p. 169. 
Gracian (sic!) mostra uma sabedoria e sensatez na experiência da vida, com o que nada agora se compara. Somos os microscópios do real, nossos romances compreendem para ver (Balzac, Dickens), ninguém compreende apenas para demandar e esclarecer. ${ }^{14}$

Essa ênfase em uma "exigência" e "esclarecimento", racionalmente fundados, no pensamento de Gracián me impressiona como uma antecipação de sua força de atração para o condenado à morte Werner Krauss e foi também determinante para as leituras de intelectuais sob a crescente ameaça sinistra do nacional-socialismo. Walter Benjamin dedicou a seu amigo Bertolt Brecht um exemplar da tradução de Schopenhauer publicado em 1931 pela Insel-Verlag com um verso da Dreigroschenoper (Ópera dos três vinténs), cujo sarcasmo (talvez ironicamente, ironicamente temperado) não era propriamente comparável com a auto-segurança da visão marxista de mundo. Todavia, a dedicatória a Brecht com a citação de Brecht acertava precisamente no desafio mental talvez mais importante dentre as reflexões de Gracián: "Pois, para esta vida o homem não é esperto o suficiente" 15 . Durante os anos de seu exílio, entre 1933 e 1940, Brecht assinalou vinte e seis dos aforismos do Oráculo ou os comentou por escrito.

Aquela pulsão tanto excêntrica quanto vital das leituras de Gracián na Alemanha não se encerra depois do fim do Segunda Guerra, embora essa pulsão devesse se impor agora contra uma vontade boa, nacional e autocrítica, que reitera a transparência e o calor do discurso iluminista ou pelo menos outra vez fortalecia. Assim o historiador da filosofia Hans Blumenberg, que pessoalmente valorizava a distância de colegas e leitores, em seu livro de 1981 Lesbarkeit der Welt (Legibilidade do mundo), reserva um capítulo

${ }^{14}$ Friedrich Nietzsche: Nachgelassene Fragmente (outono de 1773 - inverno de 1873 - 74), in Sämtliche Werke; Kritische Studienausgabe, volume VII, Giorgio Colli e Mazzino Montinari (organizadores), Munique, 1967 - 1977, p. 744.

${ }^{15}$ Sobre este episódio da história da recepção, cf. Lethen: "Im reissenden Strom der Translationen", pp. 198ss. 
elogioso ao Oráculo manual, que tendencialmente confunde frieza com observação imparcial. No entanto é possível que, no final das contas, a posição particular inevitável de tais estudos, longe do consenso benevolente da maioria, levasse a recepção alemã de Gracián a um campo minado, onde cada movimento provocasse interpretações sobrecarregadas de teor político e ideológico. Sob tais condições, seria de todo modo dificilmente imaginável um sucesso surpreendente e quase sensacional como aquele alcançado nos Estados Unidos por Christopher Maurer com sua tradução do Oráculo manual publicada em 1992, que, provavelmente na onda da ingênua literatura de autoajuda (talvez refrescantemente ingênua), alcançou uma edição de mais de cem mil exemplares ${ }^{16}$.

Mas quem era aquele autor do distante século XVII na Espanha que até hoje mantém enfeitiçada a orientação profissional e também existencial do público leitor, e cuja voz marcante ocasionalmente cremos escutar em seu texto, e por mais que seja difícil do contorno de seu pensamento extrair em nosso imaginário igualmente contornos de uma figura individual? Tão pouco concreto foi legado sobre a existência individual de Baltasar Gracián que dependemos de especulações baseadas em convergências entre seus textos e o horizonte de seu mundo histórico. ${ }^{17}$

Ele começou, encerrou e passou a maioria de seus 57 anos entre 1601 e 1658 em Aragón, aquele antigo reino ibérico, que, como vizinho oriental da Castilla de então, estava, por um lado, sob o domínio de um império contra reformista, no princípio de sua rápida queda, por outro lado, porém, este império mediava numa abertu-

\footnotetext{
${ }^{16}$ Neumeister, pp. XV e seguinte.

${ }^{17}$ Também do ponto de vista biográfico - e justamente da perspectiva mencionada, o livro de Werner Krauss sobre Gracians Lebenslehre, é inigualável - ver o capítulo "Werk und Leben", pp. 11 - 38.
} 
ra do impulso essencialmente moderno da Itália. Juntamente com sua mulher Isabel de Castilla o "rei católico" Fernando de Aragón conduzia a Espanha em um mundo moderno de início e era por isso visto por Machiavelli como o único monarca vivo que correspondia à sua provocante imagem racional do soberano político.

Dentro de Aragón e para além das fronteiras de Castilla, Gracián levava uma vida de constante mudança de domicílio, como já era típico para um jesuíta daquele tempo. Passou o primeiro ano de formação sob a custódia de um padrinho espiritual, na velha capital de Toledo, com seu olhar malicioso sobre o novo centro de Madri, só tardiamente consolidado; de volta a Aragón, ingressou na ordem, foi sagrado sacerdote e passou a primeira fase de sua condição autoral, em que somente tardiamente se inseriu, na pequena cidade de Huesca, como amigo do humanista aristocrata Vincencio Juan de Lastanosa, sob cujo nome o Oráculo manual foi apresentado aos primeiros leitores; na vizinhança da corte madrilenha, foi alçado à confessor de aristocratas poderosos e adquiriu reconhecimento retórico com a vitória das tropas castelhanas sobre os rebeldes catalães, no ano de 1646, enquanto seus superiores não gostavam que ele ameaçasse aos devotos de uma congregação de Valencia a ele confiada com a leitura de uma carta supostamente vinda do inferno.

Antes de tudo, a ordem religiosa investia Baltasar Gracián da autoridade da doutrina teológica, o que explica seu crescente domínio na argumentação racional, pois, desde a metade do século XVII e segundo a vontade de seu fundador, Ignacio de Loyola, os jesuítas supunham a mediação do princípio do Iluminismo a ser exercido pelos fins políticos da igreja católica, com vistas sobretudo ao rechaço do protestantismo. Não havia contradição institucional ou intelectual, por um lado, entre o desenvolvimento das reflexões de Gracián sobre as formas atuais de atuação da vida individual, política e discurso público em obras com os títulos de El Héroe (1637), El Político (1640, Agudeza y arte de ingenio (1641, 1648), El Discreto (1646), Oráculo manual (1647) e El Criticón (1651 - 1657), e, por outro, o professorado jesuítico. Podemos ao contrário supor que Gracián satisfazia bem as expectativas dos superiores com a 
substituição de seu nome próprio pelo de seu irmão Lorenzo, como autor de obras seculares.

Como livro de persistente êxito do autor, o Oráculo manual ocupava em seu gênero um lugar especial, porquanto aos leitores - como dito anteriormente - era apresentado antes com palavras inexatas à maneira de coletânea de pensamentos de um autor bemsucedido na Espanha e sobretudo na França. No contexto históricocultural, sem embargo, eram exceções e reflexões agudas do mais alto nível de abstração, nem antologias de concepção da vida nem "aforismos", e sim a sua forma textual ${ }^{18}$. Isso valia igualmente para o título, no qual se encontravam - junto à referência aos livros antes atribuídos a Lorenzo Gracián - três tendências contemporâneas e o leitor bem informado nas tradições devia recordar-se dos clássicos antigos: no formato manual, o sentido verbal ("manual"); com o conceito de "Orakel", a exigência conotativamente relacionada de autoridade da "prudência"; e a descrição da forma, articulada a tal prudência, mas que devia também ser empregada como "arte" ${ }^{19}$. Arbitra-se muito mais difícil a identificação de uma estrutura, em cuja disposição poderia se basear os trezentos aforismos de Gracián ${ }^{20}$. Pois, por um lado, não estava certamente na intenção do autor apresentar seus pensamentos e argumentos como sistema fechado; ao mesmo tempo, porém, elementos formais na sua sequência se tornam significativos em demasia para perder de vista a ampla dimensão da forma. Sob os traços estruturais, descobrimos a descrição decididamente diferenciada da contemporaneidade específica nos primeiros aforismos e a ênfase teológica quase surpreen-

\footnotetext{
${ }^{18}$ Acerca do lugar do Oráculo manual na história dos gêneros, $c f$. Emilio Blanco, op. cit., pp. 30 ss.

${ }^{19}$ Explicação do título e de sua motivação histórico-imagética, $c f$. von Koppenfels, op. cit., p. 171.

${ }^{20} C f$. Blanco, pp. 47 sd. E 63 ss.
} 
dente nos últimos; o acúmulo do factual nas primeiras obras sob o mesmo nome de autor e citações nos cem primeiros parágrafos "escritos" 21; a ocorrência de pensamentos reunidos ou concluídos sentencialmente em locais numericamente marcantes (por exemplo, nos aforismos 100, 150, 251; e - talvez já como passagem a um modo individual de pensar - a inclinação de Gracián a iluminar, ao longo de uma curta sequência de aforismos de determinados temas, sob diversos ângulos, e a sujeitá-los a novas questões, para então abandoná-los, dando a impressão de uma mudança abrupta, sem que fosse excluído um retorno a perguntas incisivas.

No prosseguimento da leitura pode ocasionalmente surgir uma impressão de contradição que Gracián não poderia ter controlado ou notado, a exemplo do aforismo (46) em que recomenda os leitores a resistir a impulsos de aversão espontânea e, na próxima reflexão, sugere a não se deixarem dirigir por sentimentos espontâneos de simpatia. Creio de todo modo que tal aparência de inconsistência frente ao texto não reconduz a expectativas de sistematicidade aplicadas. Pois uma vez que se prove a inflexibilidade da racionalidade de Gracián precisamente em suas contradições contra "princípios" ou conselhos absolutos e, em consequência, unilaterais - sempre casos e situações especiais pedem, de acordo com sua visão, soluções sempre soluções específicas; em segundo lugar e, sobretudo, pertence às possibilidades fascinantes de leitura do Oráculo manual poder-se perseguir os movimentos de um pensamento ágil como cadeia de acontecimentos. Tal agilidade constitui então parte, especificamente para uma "antologia" em forma de aforismos, - da dificuldade bem surpreendente, por certo a resistência do texto $^{22}$ em face de seu leitor. Pois de um aforismo para o próximo, muitas vezes dentro de um único processo de pensamento, o leitor é forçado à revisão e à troca de suas premissas. Mais significativo do que noutras coleções de aforismos (por exemplo, os de La Rochefoucauld), as reflexões de Gracián transcorrem como plurale-

\footnotetext{
${ }^{21} C f$. Blanco, p. 40.

${ }^{22} C f$. Blanco, p. 72 s.
} 
tantum (pluralidade), em sequências sempre novas do pensamento, cujas abordagens raramente raramente se deixam citar de maneira isolada. Não é raro que tais sequências elevem a complexidade das perspectivas sobre um tema específico em tal medida que ao leitor não é mais passível de consumação - sem jamais aludir à existência de um sistema mental coerente. Também por isso a leitura dos aforismos de Gracián representam um constante desafio.

Todos estes momentos de estrutura desestruturados não somente agravam o cumprimento efetivo da leitura como também tornam impossível sintetizar o conteúdo do Oráculo num plano de concretude maior que seu título. Pois este conteúdo estabelece mesmo uma multiplicidade de movimentos mentais não raramente centrifugais. Quem queira resumir logo depende de avançar certos aforismos na ordem de um argumento possível, não fornecido pelo próprio texto. Ele continuamente põe a própria contemporaneidade sob aquele diagnóstico ambivalente específico:

Todo está ya en su punto, y el ser persona en el mayor. Más se requiere hoi para un sabio que antiguamente para siete; y más es menester para tratar con un solo hombre en estos tempos que con todo un pueblo en los passados. ${ }^{23}$

Se podemos supor que Gracián se relaciona com o conceito de "ser pessoal" com a forma e capacidade da ação humana autônoma (em nossa retrospectiva: do começo dos tempos modernos), atribuiremos à primeira frase do aforismo introdutório um tom claramente otimista. Mas este otimismo logo se defronta com a experiência de uma complexidade múltipla ascendente do cotidiano social (más es menester para tratar con un solo hombre en estos tempos que con todo un pueblo en los passados). A atividade "plenamente desenvolvida" assim encontra um desafio que, para ser satisfeita, não pode se pressupor como principalmente garantida.

${ }^{23}$ Substituo a tradução para o alemão pelo castelhano do original (N. do Tr.). 
Várias reflexões do Oráculo transformam aquela primeira observação de complexidade em uma acusação da decadência moral de sua própria contemporaneidade. Assim o aforismo (280):

Hombre de lei. Está acabado el buen proceder, andan desmentidas las obligaciones, ai pocas correspondências buenas: al mejor servicio, el peor galardón, a uso ya de todo el mundo. Ai naciones enteras proclibes al maltrato: de unas se teme siempre la traición; de otras, la inconstância; y de otras, el engano $[\ldots]$

Em tal circunstância, a vontade e a necessidade sobrevivem em instituições que colapsam (sobrevivem não com altas exigências morais mas sim apenas para evitar o status de vítimas), as quais o cotidiano converte em uma estimulada "batalha contra o pior nos homens". E essa batalha se cumpre em um plano de sutileza estratégica quase não administrável, que o aforismo (13) recorda evidentemente inspirado na imagem da luta entre esgrimas, como fascinava a muitos autores a partir do mundo de Gracián:

Obras de intención, ya segunda, y ya primera ${ }^{24}$. Milicia es la vida del hombre contra la malicia del hombre, pelea la sagazidad con estrategemas de intención. Nunca obra lo que indica, apunta, sí, para deslumbrar; amaga al aire com destreza y executa en la impensada realidade, atenta siempre a desmentir. Echa una intención para assegurarse de la émula atención, y rebuelve luego contra ella venciendo por lo impensado. Pero la penetrante inteligência la previene con atenciones, la azecha con reflexas, entiende siempre

${ }^{24}$ Traduzo o esclarecimento dado pelo editor, Emilio Blanco: "Primeira e segunda intenção são termos de cirurgia que se aplicavam para a cura de ferimentos. (Gracián o emprega no sentido moral: "No sentido moral, é quando se faz algo descobertamente às claras e se tem outro fim ou desígnio oculto e que aquela ação não manifesta” (Blanco, E.: 1995, 107). 
lo contrario de lo que quiere que entienda, y conoce luego qualquer intentar de falso; dexa passar toda primera intención, y está en espera a la segunda y aun a la tercera [...]

O primeiro plano das reflexões do Oráculo não é ocupado pela malvadez do inimigo potencial e sua condenação, senão pela inteligência desafiadora e ameaçadoramente estratégica do adversário.

Tal sobrecarga permanente no cotidiano de um império que naufragava, creio, deve haver sido a razão para a resolução de Gracián em se concentrar nas circunstâncias e modos da vida secular; para aquela decisão de, no fim do livro (aforismo 251) destacar como "regla de gran maestro" que "hanse de procurar los medios humanos como si no huviesse divinos. [...] Regla de gran maestro; no ai que añadir comento". Estas palavras lembram uma fórmula que emergia nos textos de teólogos e filósofos então conhecidos face à confrontação de problemas de complexidade particular: "etsi Deus non esset” (e se não houvesse Deus). Há um dever prático, ressalte-se, de renunciar à ajuda de "meios divinos" porque justamente a confiança neles poderia levar à negligência e fraqueza no combate do cotidiano. Teologicamente, como elemento da reflexão sobre o cotidiano secular, a fórmula seria mal interpretada como sintoma de um ateísmo antecipado, que procurava se ocultar sob a forma gramatical de um irrealis ("esset"). Especialmente, no que concerne a Gracián, temos toda a razão de supor que a existência de Deus era inquestionável para ele. Se ele assim recomendava uma concentração no emprego exclusivo de "meios humanos", "como si no huviese divinos", assim se orientava a um imperativo pragmático. Só uma concentração exclusiva no mundo secular e suas estratégias parecia manter a possibilidade de sobrevivência individual.

"Pessoa" já é no primeiro aforismo o conceito central normativo do Oráculo manual, em que convergem as atribuições estratégicas mais relevantes para a sobrevivência individual - conceito que é iluminador e reiterado e advém regularmente de reflexões decisivas. Como pessoa seria pois notado o cuidado que pode converter o costume em segunda natureza [ $c f$. aforismo 238]. 
Em comparação quanto à diferenciação e sutileza da conduta que deve caracterizar a pessoa, a forma da sociedade, como palco de sua condição, é surpreendentemente elementar. Gracián pressupõe como dada e imutável existência de uma camada superior de aristocratas e funcionários, aos quais deve se adaptar do melhor modo estratégico possível, pois seu poder hierarquicamente superior - bastante independente de sua dignidade moral e de sua eficiência - não pode ser modificado ou é inalterado. O mesmo vale para classe baixa, não destinada a subir ("vulgo", "communes"), da qual a pessoa se distancia e de cuja interação deve se abster também porque, por suposto, convive com a tolice. Semelhantemente arcaica é a assimetria que se supunha permanente, mas que uma vez é explicitada entre os sexos: "Lo mejor de un hombre es parecerlo; que la muger puede afectar con perfección lo varonil, y no al contrario" (275). E ainda bastante no sentido do conceito tardio-medieval de "fortuna", a sorte aparece como um poder, que - com independência do merecimento individual - a alguns homens favorece e a outros prejudica: "Tener tanteada su fortuna $a^{25}$ : para el proceder, para el empeñarse. [...] El que la observó favorable prossiga com despejo, que suele apasionarse por los osados; y aun, como vizarra, por los jóvenes. No obre el que es infeliz, retírese, ni le dé lugar de infelicidades".

Neste simples palco da vida complexa e dramática como batalha constante devem valer duas regras básicas a que Gracián se aferra como principais - apesar de toda sua insistência na patência ante cada situação em sua correspondência singularidade. Já o terceiro aforismo recomenda que não se jogue com cartas abertas; devese manter encobertos ("cubrir") seu propósito e paixões, mas, ao mesmo tempo, estar em condições de decifrar - "descifrar” é ao longo do texto uma das palavras prediletas de Gracián - o mais am-

${ }^{25}$ Como a tradução brasileira - Oráculo de bolso e arte da prudência, trad. de Adriana Junqueira Arantes, Martin Claret, São Paulo, 2013 - omite a primeira frase, observo que entendo "tener tanteada su fortuna" como "ponderar sua sorte" (N. do Tr.) 
plamente possível a existência oculta dos outros homens. De igual importância é a compreensão da necessidade de ligar-se a outros homens, sobretudo ocupantes de posições socialmente altas, por meio do favor, que se converta em obrigação, em vez de se humilhar ou de se sujeitar: "Atención a obligar ${ }^{26}$. Los más no hablan ni obran como quien son, sino como les obligan [...]” (226).

Em sua concentração secular, a racionalidade estrita e a aparição consequente de "meios divinos", como valores morais, estes elementos centrais da concepção da vida de Gracián confirmam um efeito específico de frieza e ligação distante, sem provocar surpresas ou que sejam bastante excêntricos, em seus conteúdos e valores. Alcançam ao contrário muitas das reflexões que antes as levam a resultados convencionais a um grau de cumplicidade que podem exigir um alto preço do leitor.

Assim o Oráculo manual talvez, em seu próprio tempo, nunca teria se alçado sobre os muitos outros tratados sobre a experiência da vida se não houvesse sido escrito no estilo do então chamado "conceptismo". A verificação que o objeto e o argumento do pensamento de Gracián não é separável deste estilo pertence - por certo de modo convincente - aos lugares comuns da literatura secundária. Com muito menor clareza e consenso somos impelidos à descrição histórica do conceptismo. Os artigos de manual correntes divergem em um grau incomum e para mais somos levados porque confiam demasiado na delimitação do "culteranismo", um antônimo estilístico da mesma época, com o mesmo grau de dificuldade em ser compreendido. Sempre pode-se entender por culteranismo - falado de maneira bastante impressionista - um excesso de palavras que remete a conteúdos por elas articulados, em cujo contraste particularmente se concentra a escassez verbal acentuada no conceptismo. Ao lado disso, é de se reter que a relação do conceptismo com a palavra "conceito" menos visa ao sentido de "conceito" do que a uma variante mais próxima da palavra em inglês "conceit", ou seja,

${ }^{26}$ No sentido de "estar obrigado", "deixar alguém obrigado", Blanco, E., op. cit., p. 226.

Cad. Trad., Florianópolis, v. 41, no 3 p. 424-452, set-dez, 2021. 
"figuração ou construção de pensamentos". Trata-se assim de configurações conceituais, que consistem em elementos cênicos diversos.

O longo ensaio de Gracián sobre o conceptismo, sob o título de Agudeza y arte de ingenio, impele a reflexão, como é frequente, ademais em diversas direções, sem levar a um cômodo conceito, sobretudo sem ilustrar o fenômeno na máxima diferenciação. $\mathrm{O}$ livro pelo menos contribui para o esclarecimento da "agudeza" estilístico-intelectual do conceptismo como meio e o "ingenio" ("arte da razão") em uma perspectiva imediatamente surpreendente. Em vez de ligar a "agudeza" com qualidades formais, como de imediato se espera, o tratado a associa repetidamente com o aspecto da "substância", que, na filosofia aristotélica constitui o signo da "forma”. Já no prefácio "Al lector" fala-se de "tropos e figuras retóricas" como "fundamentos materiales" 27 do espírito; mais claramente, logo depois da agudeza como "alimento" (ou pasto) da alma e, por fim - com clareza particularmente bela - em "luz" do entendimento: "Entendimiento sin agudeza ni concepto es sol sin luz, sin rayos, y cuantos brillan en las celestes lumbreras son materiales con los del ingenio" (Agudeza y arte del ingenio, p. 439).

Sobre os 83 "discursos" da Agudeza y arte del ingenio se acumulam amplos indícios para a suposição de que Gracián atribuía ao estilo de sua fala fundamentalmente a dimensão de substância. Ao estilo pode-se "perceber, mas não definir", diz-se em um lugar (Agudeza..., p. 440). Acentua-se sobretudo que o estilo resulta da relação entre diversos elementos percebidos: "La proporción entre las partes del visible es la hermosura, entre los sonidos la consonância” (idem, p. 788). No fim, empreende-se uma pesquisa descritiva das palavras de um estilo materialmente realizado, e, mentalmente, pela forma: "Dos cosas hacen perfecto un estilo, lo material de las palavras y lo formal de los pensamientos" (idem, p. 788).

Também com relação ao próprio estilo de Gracián, à sua "força luminosa, sua "incomparável capacidade formal" e a "pirotecnia"

${ }^{27}$ Citado de acordo com a edição de Santos Alonso, in Baltasar Gracián: Obras completas, Madri, 2011, pp. 431-808, particularmente, p. 436.

Cad. Trad., Florianópolis, v. 41, no 3 p. 424-452, set-dez, 2021. 
de sua prosa, Werner Krauss vai muito além da compreensão de outro estudioso da literatura. Sua análise antes de tudo afirma a intuição que "concepto" ressalta menos "uma conceitualidade e sim, em primeiro lugar, uma relação entre as coisas", que remetem a quais palavras e não só a uma relação entre as palavras ( $c f$. Krauss, W.: 1947, p. 122). Esta compreensão permite a Krauss compreender o quanto o pensamento Gracián "leva a vida apenas através da linguagem. Ele quer, de fato, levar o movimento dos conceitos para a vida". Mas o leitor não consegue simplesmente prosseguir esse movimento de modo pleno. Ao invés, seu pensamento é tão avivado que ele, "como contraparte" do autor pode "ajudar" ou cabe a Krauss compreender que o pensamento de Gracián "leva a vida apenas através da linguagem. Ele quer, de fato, conduzir na vida o movimento dos conceitos". (Daqui, agosto 12). Mas o leitor simplesmente não consegue cumprir este movimento ou muito completamente. Seu pensamento é antes por ele ativado, de modo que pode "ajudar" ao autor "como contraparte" ou, justamente, terminar sua reflexão em plena reflexão: "O estilo da fala reflexiva de Gracián encadeia, enquanto a fala distancia. $\mathrm{O}$ autor é sempre prévio ao leitor. O sentido somente se arredonda quando se volta ao início, descobre-se na frase o contrári, se depreende o conceito de seu contra-conceito e as contradições equilibradas se diferenciam em um sistema de articulações" (Krauss, W.: op. cit., 123s).

Mais precisamente, o desafio da prosa de Gracián e as reações que provoca ao serem postas em movimento apenas são concebíveis. E assim a descrição de Krauss encoraja o passo que possibilita, mas cuja sequência filosófica não mais ousa realizar. Quando Gracián compreende a forma e a "agudeza" de sua linguagem como substância material, que deve ser sensivelmente percebida, antes de tudo aproxima o estilo do corpo humano. Mas precisamente no corpo desdobra-se a dimensão do espaço. Por isso estabelece-se a relação e o movimento entre o pensamento de Gracián a ser vivido como acontecimento espacial. E isso em um sentido não metafórico.

Pois, ao que tudo indica, o próprio Gracián compreende as estruturas originadas de suas palavras e pensamentos como configu- 
rações no espaço, analogamente às relações das coisas e corpos no espaço (precisamente, neste sentido, é significativo que ele - como também Krauss - mal sustente de pé a diferenciação entre pensamentos e coisas). Poder-se-ia dizer que os pensamentos ocorrem como os corpos celestes em uma constelação. E sendo o caso, também pensamentos e leituras se consumam no espaço, na dependência da presença de $\operatorname{corpos}^{28}$.

Essa hipótese recomenda por vários aspectos uma leitura concreta, não metafórica de muitos aforismos do Oráculo. Devemos por exemplo levantar a premissa que Gracián pensa seriamente quando escreve da "profundidade" do corpo como um espaço do pensamento: "Pecho sin secreto es carta avierta. Donde ai fondo están los secretos profundos, que ai grandes espacios y ensenadas donde se hunden las cosas de monta" (179). De maneira bastante semelhante, mas apenas na direção horizontal, evoca a sabedoria como uma corporalidade, segundo movimento palpável no espaço:

Arte en el intentar. La necedad siempre entra de rondón, que todos los necios son audazes. Su misma simplicidade, que les impide primero la advertencia para los reparos, les quita después el sentimiento para los desaires. Pero la cordura entra con grande tiento. Son sus batidores la advertencia y el recato, ellos van descubriendo para proceder sin peligro. Todo arrojamiento está condenado por la Discreción a despeño, aunque tal vez lo absuelva la ventura. Conviene ir detenido donde se teme mucho fondo: vaya intentando la sagacidad y ganando tierra la prudencia. Ai grandes vaxíos hoi en el trato humano: conviene ir siempre calando sonda (78).

28 Agradeço o primeiro impulso para essa reflexão a uma fala, na cidade de Friedrichshafen, com Gill Zimmermann (naturalmente sobre Gracián). Friedrich Kreuder me poassibilitou desenvolvê-la em sua palestra em Mainz sobre o teatro no começo dos tempos modernos. 
Mas, se os pensamentos tornam-se corporalmente percebidos, então também podem desprender sensibilidade física, por exemplo sentimentos de saciedade ou de fome:

Estómago para grandes vocados de la fortuna. En el cuerpo de la prudencia no es la parte menos importante un gran buche, que de grandes partes se compone una gran capacidad. No se embaraça con las buenas dichas quien merece otras mayores; lo que es ahíto en unos es hambre en otros. Ai muchos que se les gasta qualquier mui importante manjar por la cortedad de su natural, no acostumbrado ni nacido para tan sublimes empleos; açedáseles el trato, y con los humos que se levantan de la postiza honra viene a desvanecérseles la cabeça. Corren gran peligro en los lugares altos, y no caben en sí porque no cabe en ellos la suerte. Muestre, pues, el varón grande que aun le quedan ensanches para cosas mayores, y huiga con especial cuidado de todo lo que puede dar indicio de angosto coraçón (102)

Tal drasticidade verbal traz em compensação inclusive traumatismos corporais:

Saber tomar las cosas. Nunca al repelo ${ }^{29}$, aunque vengan. Todas tienen haz y envéz. La mejor y más favorable, si se toma por el corte, lastima. Al contrario, la más repugnante defiende, si por la empuñadura (225)

Em consequência, por fim, o sentido das palavras é expresso como produção do corpo:

Siempre se ha de llevar la voca llena de açúcar para confitar palavras, que saben bien a los mismos enemigos (267).

${ }^{29}$ Estado de rinha ou de enfrentamento ligeiro (N. do Tr.). 
O que procuro figurar como espacialização do pensamento e como espaço mental, o próprio Baltasar Gracián já reconhece como não sendo o primeiro a experimentar como uma possibilidade por ele descoberta da fusão entre reflexão e prosa. Melhor lhe parecia ser pressuposto como uma dimensão elementar de sua ambiência cultural, utilizável com consequência particular. De fato, pode-se tê-lo por uma prioridade geral para o amplo contexto da idade de ouro na Espanha $^{30}$, ou melhor: falar-se de um pano de fundo da dimensão espacial, que resultou de uma configuração singular, no limite entre a Idade Média e o começo dos tempos modernos. Contra a impressão até hoje dominante na Espanha de um "retardo" da história cultural nacional frente às sociedades da Europa central, mostra-se uma multiplicidade de sintomas que se desenvolveram amplamente na península ibérica, por volta de 1500, na mentalida do começo do tempo moderno - provavelmente por decorrência da coexistência singular das três religiões monoteístas durante os séculos precedentes. Desenvolve-se a evidência do homem como consciência (tipologicamente visto como "cartesiano"), que defrontava o mundo das coisas como observador (em vez de viver o mundo como criação de Deus com os corpos), e logo começava a dispô-las de modo mudado. Era a marca que, aos olhos de Machiavelli, fazia de Fernando de Aragón, o ideal do novo soberano.

À medida que o império mundial da Espanha convertia em sua missão o rechaço e a limitação das confissões reformadas - como uma práxis religiosa a partir da práxis do sujeito - contrapunhase àquela mentalidade móvel dos modernos uma visão de mundo tradicional, que imputava outra vez aos homens como corpos e almas sua posição fixa em um mundo concebido como espaço. Essa situação é precisamente ilustrada pela duplicidade dos heróis centrais no gênero do romance picaresco, que surge depois de

${ }^{30}$ Sobre esta conexão, $c f$., ainda sem a tese da prioridade do espaço, meu livro Eine Geschichte der spanischen Literatur (Uma história da literatura espanhola), Frankfurt am Main, 1991 - sobretudo o capítulo sobre os anos 1474 - 1556 (pp. 175 - 293) e 1556 - 1700 (pp. 294 - 473). 
1550. Como primeiro destes heróis, aponta o Lazarillo de Tormes, como sujeito, com uma ascensão limitada dentro daquela sociedade contemporânea, que o desterrara, como criação divina, a seu escalão mais baixo.

Quanto mais a Espanha, desde o século XVII tardio passava militarmente e também do ponto de vista econômico para o segundo plano, tanto mais drasticamente tinha êxito a encenação e imposição da cultura pré-moderna no espaço. Disso fazia parte a escolha de Madri como nova capital como suposto meio geográfico do império; isso se fazia visível pela construção do Escorial como claustro e palácio, na encosta oriental do palácio; o estrito ritual da corte, com os múltiplos gestos de distância do monarca e sua família face aos súditos; e sobretudo a ascensão do teatro, em Madri, como a forma mais popular de entretetimento e também de reflexão.

Bastante contrário ao processo europeu do moderno que levava a cabo a dominância da consciência, que propunha examinar e valorizar todo o material como mera "aparência", no mundo clássico espanhol, a substância e o espaço eram também apenas pensáveis como alguma modalidade do ser sem materialidade. Em suas consequências, isso é um pressuposto a não desprezar na concepção de vida de Gracián, que poucos intérpretes perceberam, porque têm descompreendido o Oráculo manual, no sentido de uma perspectiva habitual desde o iluminismo até hoje, como julgamento da "aparência" frente ao ser:

Hazer y hazer parecer. Las cosas no pasan por lo que son, sino por lo que parecen. Valer y saberlo mostrar es valer dos vezes. Lo que no se ve es como si no fuese.. No tiene su veneración la razón misma donde no tiene cara de tal. (130)

Em vez do ser desmascarado, lemos (no presente do indicativo) que a aparência o duplica. $\mathrm{O}$ aforismo (231) radicaliza este pensamento na afirmação de que um objeto não é "nada" antes que sua forma tenha alcançado o aspecto da plena conclusão: 
[...] Gozar de un golpe el objecto grande, aunque embaraça el juizio de las partes, de por sí adequa el gusto. Antes de ser todo es nada, y en el començar a ser se está aun mui dentro de su nada. El ver guisar el manjar más regalado sirve antes de asco que de apetito. Recátese, pues, todo gran Maestro de que le vean sus obras en embrión. Aprenda de la naturaleza a no exponerlas hasta que puedan parecer. ${ }^{31}$

Gracián descreve como "sentido alto" ("alteza de ánimo") o aparecimento de uma necessidade do pensamento violentamente desenvolvida: "Dondequiera que se halla, se descuella, u aun tal vez desmentida de la invidia de la suerte, rebenta por campear" (128). "Compreender-se ao se mostrar" vale por isso como pressuposto necessário da grandeza humana - de modo algum moralmente desvalorizante - e fortalece nossa tese sobre a origem histórica dessa premissa que Gracián encontrou desenvolvida particularmente na Espanha de seu tempo:

Es el lucimiento de las prendas. Ai vez para cada una: lógrese, que no será cada día el de su triunfo. Ai sugetos vizarros en quienes lo poco luze mucho, y lo mucho hasta admirar. Quando la ostentativa se junta con la eminencia, passa por prodigio. Ai naciones ostentosas, y la Española lo es con superioridad. Fue la luz pronto lucimiento de todo lo criado. Llena mucho el ostentar, suple mucho y da un segundo ser a todo, y más quando la realidad se afiança. (277)

Ao mundo somente como lugar da existência humana também pertence uma posição cosmológica concreta: "En el Cielo todo es contento, en el Infierno todo es pesar. En el mundo, como en me-

${ }^{31}$ No prefácio de seu drama El Gran teatro del mundo, Pedro de Calderón de la Barca encena o testemunho da origem do mundo como uma passagem do nada como aparecimento para a substância formada.

Cad. Trad., Florianópolis, v. 41, no 3 p. 424-452, set-dez, 2021. 
dio, uno y outro. Estamos entre dos extremos, y así se participa de entrambos" (211). As possibilidades de nossa conduta e ação recorrem mesmo neste espaço da existência: "En las grandes capacidades siempre ai grandes distancias hasta los últimos trances: ai mucho que andar de un extremo a otro" (47). Mesmo o uso da razão articula-se no espaço porque Gracián pensa em relação ao corpo:

El que se calçó al principio el entedimiento al revés, en todo lo demás prosigue desse modo: lleva entre pies lo que avía de poner sobre su cabeza; haze siniestra de la diestra, y assí es tan zurdo en todo su proceder. (268)

O pensamento no espaço esclarece singularmente a fala e o estilo de Gracián. Quando em seus conceitos e coisas, como constelações, reaparecem, os substantivos e os pronomes que os substituem devem com frequência dominar a compreensão de uma densidade excessiva. Os verbos aparecem no proscênio: "O pensamento permanece sem uma ponta verbal aguçada, porquanto Gracián tinha outra meta além de vivenciar o próprio jogo da fala" (Krauss, W.: op. cit., 125). Os verbos aparecem uma vez na forma gramatical do infinitivo, onde, enquanto "palavras de tempo", passam de um curso adquirido para arrefecerem na estática. Não raramente, a posição sintática dos verbos aguardados permanece vazia, o que faz que muitas das frases de Gracián sejam incompletas e elípticas, mas sobretudo aumenta o efeito estilístico de compressão. Ao repertório do dispositivo, cuja espacialização possibilita a percepção do leitor, também pertencem pares vocabulares como "nem/ nem", "assim como/também" e "tanto mais/tanto menos", porque sugerem simetrias, assimetrias e interdependências entre acepções e seus fenômenos de relação. Afinal, todas essas formas convergem em impressões opositivas de demasiada exigência intelectual e de concretude existencialmente fascinante. Elas penetram a prosa do Oráculo manual e põem em segundo plano a restrição somente racional da argumentação na sombra. 
Também para Werner Krauss era evidente a fascinação do pensamento de Gracián sobretudo por essa concretude. Apesar de toda admiração, Krauss não esquecia que o gesto historicamente fundamentado da substância e da forma, em oposição à reflexão do moderno, concentrada na consciência, deixou de se desenvolver após o século XVII. Por isso o retirava da filosofia como discurso e práxis da abstração - com o resultado implícito de que justamente graças àquele contraste com o moderno e, em consequência, pela ausência de filosofia, se originara a particularidade da cultura clássica na Espanha:

\begin{abstract}
A consciência do estilo conceptista não ambiciona nenhuma conceitualidade abstrata. Os conceitos aparecem como prisioneiros em trânsito pelo movimento da fala. A prosa conceptista se põe pôr assim dizer diante de uma filosofia de que a Espanha não mais se informa (Krauss, W.: op. cit., 126, itálico no original)
\end{abstract}

O espaço mental de Baltasar Gracián, originalmente frio e prémoderno, poderia ter-se originado da vida no caos de uma decadência que concedia a Krauss um apoio nos meses da cela da morte. $\mathrm{O}$ movimento intelectual dentro desse espaço não permitia apenas que seu espírito se mantivesse desperto e ativo, como também obrigava de seu corpo, quando sua extinção era coisa decidida.

Não consideraremos com a adequada gravidade a situação extrema que derivou a leitura do Oráculo manual por Werner Krauss, se encerrarmos apressadamente das pistas de sua leitura as possibilidades que sua experiência 75 anos depois poderia nos propor. Sobretudo, na Alemanha, havia desde logo dois caminhos de formas e ideologias políticas rivais, que, desde a destruição do nacional-socialismo, ocupavam as etapas recuperadas no processo do moderno - e isso significa um distanciamento crescente do mundo mental estabelecido por Gracián. Aquelas etapas tinham fortalecido, por certo com um ganho político geral, a dominância da consciência e 
da racionalidade, que foram acopladas, nos três decênios próximos passados, pela matriz da tecnologia eletrônica.

Por isso, na maioria das profissões e mais ainda nos períodos de liberdade do contemporâneo, o sujeito moderno não mais se enfrenta como observador de um mundo percebido de coisas, senão aceita a fusão cada vez mais estreita com fluxos transbordantes de informações e processamento de dados. A partir dos anos 70 e 80, com a impressão antes sentida como liberdade de que o mundo em vários sentidos resultaria de "construções sociais"; essa impressão se transformou assim na dificuldade permanente de diferençar entre informação e fatos, entre fake news e news, dificuldade a que reagimos com a nostalgia pela vivência imediata das coisas e pela confiabilidade de valores e orientações.

No entanto, este beco sem saída que baseava exclusivamente na consciência é hoje apenas de uma existência minguante é apenas uma das duas dimensões de uma disforia hoje globalmente manifesta. Converge com ela a sensação de uma sobrecarga de longa duração de complexidade cotidiana, que se integra à vida em uma nova forma temporal a ser descrita como "o amplo contemporâneo" ${ }^{32}$. Desde a virada do século XVIII ao XIX, a forma temporal da chamada "imagem histórica do mundo" nas culturas ocidentais provoca o convencimento de que na ação de escala coletiva e individual se consuma a configuração do futuro aberto (mais precisamente, a configuração do futuro aberto de uma contemporaneidade de passagem consistente no alicerce de orientações de um passado disposto atrás de nós). Contra isso, o futuro hoje parece cercar-se de perigos que se movem implacavelmente em nossa direção. Porque ao mesmo tempo o passado não se mantém recuado (antes de tudo, capacidades de raios eletrônicos não concedem esquecimento algum, sequer o esquecimento da forma de tempo precedente da "consciência histórica"), todos os fenômenos, pensamentos e

${ }^{32}$ A respeito (com todo o detalhamento), meu livro Breite Gegenwart (O Amplo contemporâneo), Berlim 2010 e Nach 1945 - Latenz als Ursprung der Gegenwart (Depois de 1945 - latência como origem da contemporaneidade, Berlim, 2012.

Cad. Trad., Florianópolis, v. 41, no 3 p. 424-452, set-dez, 2021. 
possibilidades encontram-se reunidos num contemporâneo sempre mais amplo, que não é mais um contemporâneo da transição, mas sim, de pretensão sobrecarregada em termos de complexidade.

$\mathrm{Na}$ interseção de consciência e software com a nossa "ampla contemporaneidade" a nostalgia por experiências imediatas de sentido e valores confiáveis se transforma em necessidade existencial e elementar, agora conteudisticamente mal descrita. E essa necessidade é há alguns anos usada no estilo da política por duas tendências opostas e independentes que, de um ponto de vista decisivo, são, sem dúvida, de função equivalente, de modo que não têm a complexidade vivida com gestos de efeitos elementares e conceitos de clareza carente. A uma das duas variantes quero caracterizar como "política da ressonância", pois não aposta em sua concordância e em sua solidariedade incipientes como fundamento, senão em uma ressonância provocada pela impressão de figurada autenticidade. Nós todos conhecemos mestres de tal política de ressonância, com seu talento de encobrir posições e estratégias incoerentes, e ligados a potenciais partidários pela impressão de um tom direto e não simulado.

No outro lado do aspecto político-público, a "correção política" subestima a complexidade de nosso presente com sua postulação no sentido de que normas e conceitos estratégicos do passado, como se deram antes de tudo na "visão histórica do mundo", hoje se estendam à solução de problemas de curto e longo prazo. O contraste entre correção política e política de ressonância pode esclarecer a razão pela qual hoje em dia cada vez mais sociedades se crêem num processo de divisão inconciliável, que se estende mais profundamente ao oposto político do passado. É claro que hoje em dia partidos e protagonistas sem exceção afirmem (e devem afirmar) serem, eles próprios, a única alternativa à divisão, tanto paralisante quanto perigosa entre dois polos, de subestima da complexidade. Constitui indagação bem diferente, se uma alternativa como essa faz de fato parte da atual cena política.

Em face do Oráculo manual, de Baltasar Gracián, contudo, formula-se a pergunta antes existencial que política sobre a maneira como poder-se-ia pois se mostrar uma possibilidade legítima - e 
penso eu: politicamente tranquila, mas talvez ao mesmo tempo irrelevante - de satisfazer a nostalgia individual, sem incorrer na esteira das versões correntes de subestima da complexidade. Essa indagação ajudou-me a compreender a fascinação com que reagi por meses ao texto de Gracián, durante sua tradução, e com que via reagirem os amigos que comigo o leram. Estava na borda da fascinação pelas observações, argumentos racionais ou expressões do autor. Tais conteúdos pertencem ou ao mundo dramático do século XVII ("a vida como batalha") ou se acomodam ao nível de banalidade da hoje tão popular literatura de "auto-ajuda" ("é melhor envolver outros a vencê-los").

A fria concretude que se originava no espaço do pensamento de Gracián me fez realmente sentir aquela concretude da singularidade e tridimensionalidade dos pensamentos, assim como dos fenômenos, enquanto a imagem do autor permanecia em uma mínima promessa de concretude. Por certo, essa concretude apenas existia nas minhas imaginações provocadas pelo texto; era uma concretude que eu não podia levar além do texto de Gracián para outros mundos, o que não poderia ter sido diferente para Werner Krauss e para o trabalho no livro sobre Gracián.

Revisão

Werner L. Heidermann e Maria Aparecida Barbosa.

Recebido em: 09/05/2021

Aceito em: 30/07/2021

Publicado em setembro de 2021

Luiz da Costa Lima. E-mail: 118danil@gmail.com. ORCID: https://orcid. org/0000-0002-8906-9826. 